\section{Demarcar é aproximar}

Por Moema de Rezende Vergara

Museu de Astronomia e Ciências Afins/MCTI (moema@mast.br)

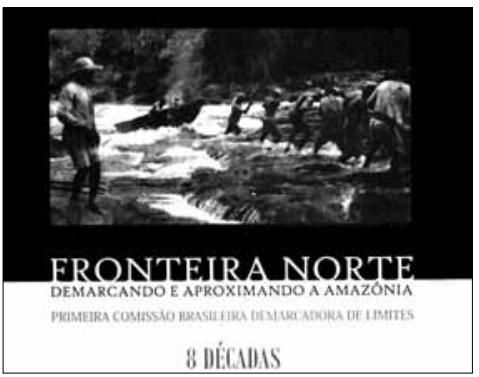

BRASIL. Ministério das Relações Exteriores.

Coordenação Geral das Comissões

Demarcadoras de

Limites. Primeira

Comissão Brasileira

Demarcadora de

Limites. Fronteira

Norte: demarcando e aproximando a

Amazônia - PCDL

8 Décadas. Belém:

FUNAG/PCDL, 2011.

293 p. il. ISBN 978-85-

$7631-283-3$

A tarefa de resenhar é um desafio, no qual o resenhista pode tomar vários caminhos, como fazer uma apresentação do conteúdo do livro para os futuros leitores, estabelecer uma relação entre o livro em questão com o estado da arte de sua área disciplinar, demolir os esforços do autor ou, como já aconteceu em vários momentos da história, iniciar uma polêmica, o que pode ser bastante fértil. A trilha por mim escolhida é a do diálogo, entabulando uma conversa com este livro, fazendo emergir experiências e ideias não só sobre a prática de demarcar, mas refletir um pouco sobre alguns aspectos do processo de formação do território brasileiro.

Agora minha missão é apresentar um belo livro realizado pela Primeira Comissão Brasileira Demarcadora de Limites (PCDL) em comemoração aos seus oitenta anos de existência. Esta Comissão é um órgão do Ministério das Relações Exteriores, situado em Belém (PA), que tem por função demarcar e densificar (colocar marcos) os limites internacionais das fronteiras setentrionais do Brasil. As meridionais são de responsabilidade da Segunda Comissão Brasileira Demarcadora de Limites (SCDL), sediada no Rio de Janeiro.
A PCDL é responsável pelas fronteiras com Peru, Colômbia, Venezuela, Guiana, Suriname e Guiana Francesa. Sendo assim, uma possibilidade de estrutura do livro seria tratar de cada país como um capítulo à parte, com seus respectivos tratados e percursos, acrescentando o fato de que a chancelaria brasileira sempre lida com os assuntos de fronteira em acordos bilaterais. No entanto, não é isto o que ocorre neste livro, que faz um recorte horizontal, mostrando o que é comum em todos os trabalhos de demarcação na fronteira amazônica do Brasil. O recurso escolhido pelos autores foi produzir este livro comemorativo como um álbum de fotografias, em sua maior parte realizadas pelo fotógrafo da Comissão, Raimundo Araújo. Assim, ao folhear esta obra, o leitor verá lindas paisagens, as condições de trabalho nos acampamentos, o cotidiano dos demarcadores, o encontro com a população indígena e os rostos dos trabalhadores - figuras que frequentemente ficam anônimas nos relatos oficiais. Há também um capítulo dedicado às observações astronômicas, fundamentais para a determinação das coordenadas geográficas. $\bigcirc$ destaque foi dado aos instrumentos científicos, como os teodolitos, e à telegrafia, via importantíssima para o cálculo da longitude. O leitor verá que, em campo, sob o calor tropical, o guarda-sol é para proteger o instrumento, para que não sofra grandes alterações nas suas aferições, e não para os técnicos que os operam. Tendo em mente a delicadeza destes equipamentos, tornam-se mais dramáticas as imagens das travessias dos rios, quando fica clara a força dos trabalhadores, que frequentemente tinham que carregar nas costas a embarcação, sobre lajes e subindo cachoeiras. Para um público não familiarizado com aquela região, esta sequência de imagens é bastante reveladora, pois geralmente se pensa no Amazonas como um mar de água doce, de fácil navegação, retrato que passa a ser desconstruído por meio das fotografias do livro.

Após seguir os passos dos demarcadores, cheguei ao último ponto do livro, com a frase "demarcar é aproximar". O atual chefe da PCDL, o cartógrafo Dauberson Monteiro da Silva, explica-me que esta máxima fora cunhada por

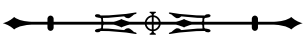


seu antecessor, Coronel Ivonilo Dias Rocha, para quem era necessário superar o conceito tradicional de fronteira como barreira, mas perceber o limite territorial como uma oportunidade de aproximação entre povos e culturas. Esta afirmação suaviza a visão geopolítica de segurança nacional e aponta para uma abordagem antropológica de fronteira. Elegantemente formulada, a afirmação também pode ser vista no trabalho de demarcadores de outras épocas, mesmo antes da institucionalização da PCDL.

No binômio demarcar/aproximar está subsumido o ato de conhecer. Os trabalhos de demarcação de fronteira aconteciam desde o período colonial, quando era necessário estabelecer os limites entre Portugal e Espanha na América. Quando o Brasil tornou-se independente, as dimensões do território eram uma noção vaga tanto pela falta de mapeamento quanto de exploração de sua totalidade. $\bigcirc$ Império investiu na demarcação e no conhecimento do território, produziu duas cartas nacionais, mas este esforço não se completou totalmente. Restou à República concluir a demarcação das fronteiras nacionais, muitas vezes ditada pelo ideário do Império. Assim, este empenho em delimitar o país se desenrolou ao longo dos séculos e, ao ler os relatos destas viagens de exploração/demarcação, observo que elas também eram meios de conhecimento dos aspectos naturais, das geografias e das gentes, de partes do território desconhecidas pelo poder central. Estes textos, escritos inicialmente em forma de relatório, eram geralmente publicados em livros e artigos de revistas de grande circulação, tornando próximo o que estava distante para o restante da sociedade. A tarefa de conhecer e mostrar o país para os brasileiros estava sempre presente, bem como o desideratum de se falar sobre as fronteiras mais longínquas.

Já pesquisei na $\mathrm{PCDL}$, como também na SCDL. Como historiadora, é uma vivência fantástica. Não só pela possibilidade de se encontrarem, no mesmo local, fotos, relatórios, livros, mapas, instrumentos antigos, entre outros artefatos. Pude ver a história viva em vários sentidos, por exemplo, quando presenciei um grupo de demarcadores se preparando para uma viagem, preocupados com o regime dos rios, analisando o melhor dia da partida, enquanto eu lia sobre a Comissão Mista Brasil-Bolívia do final do século XIX. Era como se passado e presente convergissem no mesmo momento naquela sala. Esta sensação se repete com frequência sempre que vou a uma das Comissões. Ao ver as páginas dos relatórios de outros tempos marcadas com lápis, e quando os comissários me explicam suas atividades, vejo que a história para eles é algo cotidiano, presente na prática profissional, pois ainda têm que se remeter a mapas antigos, relatórios, tratados e instruções ministeriais para executarem suas missões atuais. Assim, para um historiador da ciência, é incrível ver, no mesmo espaço, modernas técnicas de demarcação e vestígios da história de outros períodos. Esta perspectiva está presente na edição deste livro, pois cada capítulo inicia com um mapa antigo, servindo de fundo para os fragmentos de documentos do século $X X$ e indicando o assunto a ser tratado pela série de fotos subsequentes. O resultado é uma composição de grande valor estético.

$\mathrm{Na}$ epígrafe do livro, há uma citação de Mário Quintana, extraída do poema "A terra". A citação, em uma interpretação livre, versa sobre a extraordinária capacidade da cartografia em desenhar meridianos na Terra, a qual se mostra indiferente a eles, embora sejam importantes aos seres humanos que nela habitam. O poema nos induz a pensar que estas linhas - que não estão na natureza - são puras construções humanas e estão sempre se movendo. O poeta é sagaz ao perceber que isto contradiz a sensação de que o mapa é uma entidade 'atemporal' e uma realidade acabada. Ao conviver por poucos períodos nas comissões demarcadoras, pude ver que estas linhas são mais maleáveis que o senso comum pode supor. $\bigcirc$ trabalho dos demarcadores não é apenas densificar as fronteiras, mas também conhecer um território que é nacional, portanto nosso, que, no entanto, ainda possui aspectos a serem descobertos. Talvez por isto mesmo o caráter geopolítico das relações internacionais não seja o foco deste livro. Seu mérito está em apresentar ao público do século XXI partes do território onde vive. Em outras palavras, demarcar é aproximar - no espaço e no tempo.

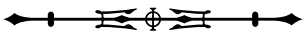

